\title{
SEXUALITY OF INDIVIDUALS WITH PHYSICAL DISABILITIES - SOCIAL MYTHS AND PREJUDICES
}

\author{
Zuzana Ivanová \\ MA, Comenius University in Bratislava, Slovakia \\ Terézia Harčaríková \\ Doc. PaedDr., PhD., Comenius University in Bratislava, Slovakia \\ e-mail: harcarikova@fedu.uniba.sk, Slovakia,
}

\begin{abstract}
Sexuality and the life of an individual with a physical disability is a strange and unique phenomenon associated with many myths and prejudices for many people. The article defines sexuality with all functions and impact on the quality of life of both the intact population and individuals with physical disabilities.

The next part describes sexuality of physically handicapped and its specifics. Finally, the article defines the most common social myths and prejudices about sexuality of individuals with physical disabilities and partner life, which is also described in the section ,, výskumu“".
\end{abstract}

Keywords: physical disability, sexuality, disability, prejudice, quality of life.

DOI: http://dx.doi.org/10.23856/3714

\section{Sexualita}

Sexualita je neoddelitel'nou súčast'ou našich osobností, či už si to uvedomujeme, alebo nie. Je ovplyvňovaná už počas ranného detstva samotnou výchovou a rodičovskými vzormi, je l'udskou prirodzenost'ou a sprevádza nás po celý život.

Sexualita je zároveň ovplyvňovaná samotnými mentálnymi procesmi, správaním a fyzickými vlastnost’ami človeka, ktoré súvisia $\mathrm{s}$ pohlavím, erotickou láskou a prít'ažlivost'ou, rozmnožovaním, pohlavným sebauspokojovaním, psychikou a pohlavným pôžitkom vyplývajúcim z intímneho zbližovania, čo zároveň tvorí celkovú identitu každého jednotlivca.

Pre pochopenie pojmu sexualita, je vel'mi dôležité, aby sme si uvedomili, že pod sexualitou si nepredstavujeme len pohlavný styk, ale aj znalost' l'udského tela, najrôznejšie prejavy správania sa a vlastného prežívania, romantiku, emócie, lásku či vzt’ahy ako to uvádza aj Thorová a Jůn (2012). L’udská sexualita je vyjadrením sexuálneho vnímania a intimity medzi l'ud'mi či už intaktnými, tak aj telesne postihnutými. Z psychologického hl'adiska, je sexualita prostriedkom cieleným na vyjadrenie naplnenia lásky, medzi mužom a ženou. Biologicky je to prostriedok, prostredníctvom ktorého je diet'a koncipované a rodokmeň sa rozširuje o novú generáciu.

Z definície sexuality vymedzujeme zároveň aj jej funkcie v živote človeka. Biologicky slúži sexualita najmä k plodeniu detí a zachovaniu l’udského rodu. Už Siegmund Freud prišiel s myšlienkou, že hybnou silou l'udského správania sú dva základné pudy a to pud sexuálny a pud smrti. Zároveň tvrdil, že narušený vývoj sexuality je jedným z príčin vzniku neurotických porúch. Biologická a telesná funkcia sexuality sa vo vel'kej miere týka l'udských reprodukčných funkcií, vrátane cyklu l'udskej sexuálnej reakcie. 
Psychologická funkcia sexuality je dôležitým aspektom vzt’ahu dvoch l'udí. Sexuálna prít'ažlivost' medzi partnermi môže byt' prejavom vzájomnej lásky a nehy, prehlbuje intimitu, vzájomnú dôveru a blízkost'. Emocionálna funkcia sexuality zahŕňa väzby medzi jednotlivcami, ktoré sú vyjadrené prostredníctvom hlbokých pocitov alebo fyzických prejavov lásky, dôvery a starostlivosti. Sociálna fukcia sexuality je utváraná vplyvom l'udskej spoločnosti na sexualitu jednotlivca, zatial' čo spiritualita každého z nás, sa dotýka duchovného spojenia jednotlivca s ostatnými.

Janiš a Marková (2007) opisujú funkcie sexuality nasledovne.

Medzi základné funkcie zahŕňajú reprodukčnú funkciu sexuality, v zmysle významu zabezpečenia neustáleho rozmnožovania. Prostredníctvom komunikačnej funkcie pohlavný styk môže byt' jedným z prostriedkom nadviazania kontaktu. Jedná sa o vel'mi intímny kontakt, v ktorom vzájomne partneri uspokojujú svoje potreby, vnímajú jeden druhého a spolupracujú vo vzájomnej interakcii. Funkcia redukovania napätia je úzko spojená s fyzickou potrebou. Jedná sa o uvol'nenie napätia a dosiahnutie celkového uspokojenia. Dôležitou funkciou je tiež funkcia prestíže. V tomto prípade môže mat' sexuálny život vplyv na spoločenské postavenie jedinca. Táto funkcia je spojená so sebadôverou a sebavedomím. Jednotlivec žijúci uspokojivým sexuálnym životom, pôsobí sebavedome na okolie a vyžaruje úspechom.

K týmto hlavným funkciám Šilerová (2004) dopíňa ešte niekol'ko subfunkcí sexuality, kde väčšina $\mathrm{z}$ nich je spojená $\mathrm{s}$ pozíciou mladého jednotlivca $\mathrm{v}$ spoločnosti a $\mathrm{v}$ skupine priatel'ov. Sú to:

- vplyv na vytváranie vzt’ahov s l’ud'mi opačného pohlavia,

- podpora schopnosti založit' rozvíjat' intímne vzt'ahy,

- rast sebaúcty a sebaistoty, budovanie osobnej identity,

- pomáha vytvárat' systém individuálnych morálnych a etických hodnôt,

- pomáha vybudovat' emocionálne nezávislost' na rodičoch, vyjadrenie odporu, protestu rodičom,

-získavanie sociálneho statusu v skupinách,

- vyjadrenia, nepriatel'stva a agresie,

-útek z nepohodlného prostredia.

Sexualita, jej aspekty či funkcie majú priamy dopad na život každého jednotlivca a to intaktného aj jednotlivca s akýmkol'vek zdravotným oslabením a vo výraznej miere ovplyvňuje kvalitu života každého z nás. WHO definuje kvalitu života nasledovne: „,Kvalita života je to, ako jednotlivci vnímajú svoju pozíciu v živote - v kontexte kultúry a hodnotových systémov v ktorých žijú a vo vzt’ahu $k$ svojim ciel'om, očakávaniam, štandardom a záujmom. “ Z toho vyplýva, že pokial' by sme sa venovali sexualite, ako jedným z aspektov ovplyvňujúcim kvalitu života, môžeme prejavy sexuality považovat' za jeden z prostriedkov dosiahnutia životných ciel'ov. Je však vel'mi dôležité, aby sa sexualita formovala počas celého života, nebola odmietaná či potláčaná, ale aby bola postupne rozvíjaná a budovala sexuálne zdravie. ,Sexuálne zdravie vyžaduje, aby sa $k$ sexualite a sexuálnym vztahom pristupovalo pozitívne a súctou a aby mal človek možnost' viest' uspokojujúci a bezpečný sexuálny život bez nátlaku, diskriminácie a násilia. Dosiahnutie a udržiavanie sexuálneho zdravia vyžaduje rešpektovanie, ochraňovanie a napĺn̆anie sexuálnych práv všetkých l'udí. “WHO (2002).

Sexuálne zdravie je budované sexuálnou orientáciou a sexuálnou identitou. Sexuálnou orientáciou rozumieme menej či viac vyhranenú eroticko-sexuálnu náklonnost' voči určitému pohlaviu. Sexuálna orientácia postihuje aj kultúrne, politické, právne, filozofické, morálne , etické a náboženské aspekty života. Sexuálna orientácia je prít’ažlivost' k osobám rovnakého 
alebo rozdielneho pohlavia. Súčast’ou sexuálnej orientácie je aj asexualita, vyznačujúca sa absenciou sexuálnej orientácie a môže byt’ označovaná aj ako nulová orientácia. Asexuálny jednotlivci nereagujú na erotické stimuly a žiadny podnet v nich nevyvolá túžbu po telesnom styku.

$\mathrm{Na}$ dokreslenie toho, čo je sexuálna orientácia, treba brat’ do úvahy nielen sexuálnu stránku, ale aj d'alšie faktory. Napríklad životný štýl človeka, to, nakol'ko sa identifikuje so svojou orientáciou, rolou, sexuálne správanie, sexuálne fantázie a emócie. Sexuálna identita človeka je definovaná ako charakteristiky jednotlivca, spolu aj s jeho sociálnymi vzt'ahmi a rovnako aj s rolami, ktoré si vytvára, čím vzniká osobná definícia toho, kým človek je, kým bol, kým si želá/neželá byt' a kým cíti, že by sa mal stat'. "Identita človeka následne dotvára jeho seba-koncept” Oyserman, Elmore a Smith (2012), teda to, ako sa človek chápe, a tiež istý obraz o sebe, ktorému človek verí Baumeister (1999). "Dôležitú rolu hrajú skúsenosti a záväzky v živote jedinca, a v konečnom dôsledku fakt, či jeho identita dosahuje počas života istej integrácie, stability a celistvosti “ Erikson (1968).

Z Eriksona vychádzal aj Marcia ktorý vytvoril teóriu identity a do popredia uvádzal predovšetkým exploráciu a objavovanie, a tiež záväzok, či zodpovednost', ktorú človek v priebehu života postupne prijíma.

"Pri vývoji identity v jeho poňatí dochádza $k$ prechodu rôznymi stavmi identity, a to konkrétne difúznou identitou, predčasne uzavrenou identitou, obdobím moratória, až po stav dosiahnutej identity” Marcia (1980).

Identitu človeka považujeme zároveň aj za výsledok vplyvu sociálnej interakcie a vplyv okolia na vývoj identity je badatel'ný po celý život, na základe čoho je aj samotná identita do istej miery v priebehu času flexibilnou Mead (1934).

\section{Telesne postihnutí a sexualita}

Každý jednotlivec potrebuje v živote kontakt so spoločnost'ou bez ohl'adu na jeho rasu, pohlavie, rolu, spoločenské postavenie či zdravotný stav.

Pojem postihnutie sa spravidla označuje ako zdravotné znevýhodnenie, ktoré ako už vyplýva z názvu, znevýhodňuje jednotlivca v spoločnosti, či v osobnom živote a bráni mu vykonávat' bežné činnosti tradičnými metódami. Fyzické postihnutie je prepojené $\mathrm{s}$ fyziologickými poruchami, deformáciami alebo anatomickými zmenami a môže postihovat' akúkol’vek čast' tela či orgánu či viacero častí a orgánov súčasne. Zdravotné postihnutie, značne ovplyvňuje vývoj sexuality, preto je kl'účovým faktorom zdravého a plnohodnotného partnerského života otvorená komunikácia. Medzi bežné komunikačné oblasti patrí: plánovanie intímnej aktivity, hnev, strach, frustrácia a iné. Fyzické postihnutie často vedie k zmenenej sexuálnej funkcii, ktorá môže negatívne ovplyvnit' vlastný obraz a sebaúctu a tým celkové psychické zdravie. Po fyzickej stránke je jednotlivec s telesným postihnutím obmedzený svojimi pohybovými limitmi či absenciou fyzickej sily. Napriek tomu, aj jednotlivec s telesným postihnutím je schopný prejavovat' sexualitu. "Prejavy sexuality, či sexuálny život osôb bez postihnutia a osôb s miernym telesným postihnutím sa pritom nemusí príliš lísit'." (Mandzáková a Horňák, 2009).

Napriek tomu pri t'ažšom stupni alebo type telesného postihnutia sa môžu objavit' vážne problémy sexuálneho vývoja, ktorý zapríčiňuje problémy od nedostatku kamarátskych vzt’ahov po úplnú izoláciu a absenciu akéhokol'vek spoločenského kontaktu. 
Pritom l'udia, ktorí nemali možnost' normálnych spoločenských kontaktov v detstve, sa stávajú osobami zakomplexovanými, bezradnými, uzavretými do seba a čoraz viac sa vzd'al'ujú od ostatnej spoločnosti.

$\mathrm{K}$ určitému rozporu $\mathrm{v}$ sexualite jednotlivca $\mathrm{s}$ telesným postihnutím dochádza aj vplyvom obmedzenej funkčnej schopnosti telesne postihnutého jednotlivca. Libor Novosad (2002) odporúča, takéhoto jednotlivca orientovat' na zážitkovo ponímanú sexualitu spojenú s trpezlivost'ou, porozumením, ochotou či experimentom s pomôckami.

Medzi problémy v sexuálnom živote postihnutých zarad’ujeme: Kracík (1992), Klimek (2001)

-izolácia od intaktnej populácie,

- nedostatok možností rekreácie a rehabilitácie - nedostatok súkromia a príležitostí $\mathrm{k}$ partnerským vzt'ahom,

-nedostatok špecializovaných zariadení, kde by osoby s postihnutím mohli prežívat' zážitky sexuálneho života,

- ostych a neschopnost' oslovit' partnera priamo ,

-spoločenské bariéry - predsudky verejnosti, ktoré stoja proti láske a sexuálnym vzt'ahom medzi l'ud'mi s postihnutím,

- architektonické bariéry,

- nedostatok informácií pre všetkých zainteresovaných činitel'ov,

- nedostatok možností kvalitnej a včasnej sexuálnej výchovy,

- nedostatok vhodných kompenzačných a protetických pomôcok,

- nedostatočná ponuka odborných služieb a poradenstva $\mathrm{v}$ oblasti sexuálnych a partnerských vzt’ahov.

\section{Spoločenské mýty a predsudky o sexualite jednotlivcov s telesným postihnutím}

Sexualita je kl'účovým aspektom l'udského rozvoja a identity, no l’udia so zdravotným postihnutím sa často stretávajú so sociálnymi a politickými prekážkami pri dosahovaní zdravých, autonómnych intímnych vzt'ahov. Napriek tomu, príležitost' spájat' sa s ostatnými l'ud'mi oboch pohlaví, či už v spoločnosti, v škole alebo v práci, je dôležitá pri rozvíjaní dôvery a sociálnych zručností. Avšak niektorí jednotlivci s telesným postihnutím môžu mat' menej príležitostí na formovanie spoločenských a sexuálnych vzt'ahov z mnohých dôvodov, vrátane:

- v dôsledku závislosti od ostatných pri každodennom živote,

- v dôsledku nízkej sebadôvery a podceňovania sa,

-v dôsledku nedostatočnej schopnosti vediet', ako vyjednávat' vzt'ahy a vyjadrit' svoju sexualitu,

-v dôsledku obmedzenej sociálnej skúsenosti alebo fyzických obmedzení.

Kozáková In Volfová a kol. (2008) uvádza, že hoci sa v priebehu posledných desat'ročí mnohé zmenilo, musí často ešte aj dnes človek so zdravotným postihnutím prekonávat' množstvo predsudkov a bariér, rovnako tak i vlastných mylných predstáv týkajúcich sa sexuality. Podl'a Eisner (2010) sa aj v samotnej oblasti sociálnych služieb vytvárajú mylné predstavy, pretože sa otázkam sexuality nikto nevenuje do hĺbky, ale len povrchovo. Spoločnost' inklinuje spájat' postihnutie s asexuálnost'ou a často označuje sexuálne správanie. Častokrát obmedzený prístup k informáciám spôsobuje mylné predstavy o intímnom živote či možno niekedy nereálne predstavy o rodinnom a intímnom živote postihnutých. Z toho 
vyplýva, že predsudky sú vytvárané na základe nevedomosti alebo nedostatočnej informovanosti v danej oblasti, ktorý je často ovplyvňovaný názormi, s ktorými sa stretávame v spoločnosti. „Prakticky všade vo svete osvietenia odborníci konštatujú, že úroveň poučenia o sexualite je medzi l’ud'mi nedostatočná. To umožňuje, aby sa vo verejnom mienení a v sexuálnej praxi l'udi stále znovu a znovu objavovali falošné mýty a predsudky. Za všetky ostatné menujeme dva najvýznamnejšie, mýtus o škodlivosti onanovania a mýtus o škodlivosti antikoncepcie. "Zvěřina (2003).

Medzi najčastejšie mýty a predsudky by sme mohli zaradit' nasledujúce: asexuálni,

-Jednotlivci s postihnutím nepocitujú sexuálnu túžbu, sú nevinní ako deti, sú

- sexuálna výchova $\mathrm{k}$ niečomu tak prirodzenému, ako je sexualita, nie je potrebná,

-l'udia s postihnutím, $\mathrm{v}$ tomto prípade $\mathrm{s}$ mentálnym postihnutím, majú extrémne vyvinutý sexuálny pud, sú promiskuitný, hypersexuálny, infantilné.

- títo l'udia, nie sú schopní hlbších intímnych a emočných vzt'ahov, ich prejavy sú

Drábek (2013) uvádza výroky, ktoré obsahujú predstavy o druhých l'ud'och a významne sa dotýkajú osôb so zdravotním postihnutím:

- uspokojivú súlož možno dosiahnut' iba s dokonalou erekciou,

- l’udia so zdravotným postihnutím sú asexuálne bytosti,

-intímny kontakt musí viest' k pohlavnému styku,

-zdraví partneri l'udí s postihnutím musia byt' úchylní,

- l'udia s mentálnym postihnutím musia často masturbovat',

- l'udia so zdravotným postihnutím by nemali mat' deti.

Všetky bariéry, mýty, predsudky či predstavy v značnej miere ovplyvňujú život jednotlivca so zdravotným znevýhodnením. Pokial' s takýmito prejavmi prichádza do priameho kontaktu, môžu Vážne poznačit' jeho sebavedomie a vnímanie vlastnej osobnosti čo so sebou nesie mnoho nadväzujúcich problémov v osobnom aj spoločenskom živote. Okrem toho, v značnej miere môžu obmedzovat' slobodu telesne postihnutých a ich snahu o úplné osamostatnenie sa. V dôsledku nedostatočnej osvety, predpojatosti a zaujatosti i nad'alej budú v spoločnosti pretrvávat' mylné predstavy o sexualite a partnerskom živote telesne postihnutých. Pokial' sa tieto nedostatky neodstránia, spoločnost' nebude pripravená na úplné začlenenie jednotlivcov s telesným postihnutím do spoločnosti a tým teda nebude schopná vytvorit' pre nich také podmienky, aby telesne postihnutí jednotlivci mali rovnaké možnosti a príležitosti ako aj intaktní.

\section{Z výskumu}

Výskumná čast' je zameraná na spoločenské mýty a predsudky o sexualite jednotlivcov s telesným postihnutím. Výskum bol realizovaný prostredníctvom kvalitatívnej metódy a to pološtrukturovaným rozhovorom. Stretnutia s respondentmi sa realizovali jednotlivo na mieste a v čase, ktorý vyhovoval každému respondentovi. Počas rozhovorov sme prihliadali na fyzický aj emocionálny stav respondentov.

Hlavným ciel'om výskumu bolo zistit', či sa v spoločnosti aj dnes vyskytujú mýty a predsudky o sexualite a partnerskom živote jednotlivcov s telesným postihnutím. 
Naše výskumné otázky vychádzali čiastočne z mýtov a predsudkov, ktoré má spoločnost' o partnerskom a intímnom živote jednotlivcov s telesným postihnutím, ako sme uvádzali v teoretickej časti.

Výskumná otázka č.1: Stretávajú sa jednotlivci stelesným postihnutím s nepochopením v spoločnosti pri otázkach partnerského života a zakladania si rodiny?

Výskumná otázka č.2: Vyskytuje sa v spoločnosti stále množstvo mýtov o sexualite jednotlivcov s telesným postihnutím, ako napríklad, že u nich absentuje možnost' zakladania rodiny alebo že takýto jednotlivci nemôžu nadviazat' intímny vzt'ah?

Výskumnú vzorku sme si stanovili v súlade s obsahom príspevku. Výskumnou vzorkou boli jednotlivci s telesným postihnutím v partnerskom vzt’ahu či manželstve. Rozhovory sa realizovali prostredníctvom osobných rozhovorov na miestach vybraných samotnými respondentmi. Respondentov sme vyberali na základe odporúčaní od kolegov z katedry špeciálnej pedagogiky či zo strednej školy na Mokrohájskej 3. V nasledujúcej tabul'ke poskytujeme stručnú charakteristiku respondentov.

\section{Charakteristika respondentov}

Tabul'ka 1

\begin{tabular}{|c|c|c|c|c|c|}
\hline Meno & Druh postihnutia & Pohlavie & Vek & $\begin{array}{c}\text { Geografická } \\
\text { poloha }\end{array}$ & Stav \\
\hline Ján & DMO,kvadruparéza & Muž & 47 & Bratislava & $\begin{array}{c}\text { V partnerskom } \\
\text { vzt'ahu s } \\
\text { partnerkou }\end{array}$ \\
\hline Peter & DMO,kvadruparéza & Muž & 38 & Bratislava & Ženatý \\
\hline Janka & DMO,kvadruparéza & Žena & 40 & Bratislava & Vydatá \\
\hline Lucia & Hydrocefália & Žena & 38 & Bratislava & $\begin{array}{c}\text { V partnerskom } \\
\text { vzt'ahu s } \\
\text { partnerom }\end{array}$ \\
\hline Dominika & DMO,kvadruparéza & Žena & 22 & Bratislava & $\begin{array}{c}\text { V partnerskom } \\
\text { vzt'ahu, s } \\
\text { partnerkou }\end{array}$ \\
\hline
\end{tabular}

Rozhovory boli realizované počas troch týždňov na prelome mesiacov Marec a Apríl v roku 2019. Prvý rozhovor sme realizovali s Jankom, v budove IPR na Mokrohájskej v Bratislave. Janko bol od začiatku vel'mi príjemný, priamy a pôsobil uvol'nene. Rozhovor trval približne dve a pol hodiny a zúčastňovali sme sa na ňom len vo dvojici. Počas rozhovoru nás raz vyrušila klientka centra, avšak so situáciou sme sa vysporiadali a d'alej pokračovali v rozhovore. Uvol'nenú a dôvernú atmosféru daná situácia neovplyvnila. Druhý rozhovor sme uskutočňovali s respondentkou Luciou, rovnako v centre IPR na Mokrohájskej, ktorá bola takisto od začiatku vel'mi uvol'nená a ochotne zodpovedala naše pripravené ale aj doplňujúce otázky.

Tretí rozhovor s Pet'om prebiehal v budove školy na Mokrohájskej 3. Respondent pôsobil vel'mi milo, ústretovo a uvol'nene. Predpokladáme, že jeho príjemný prejav bol výsledkom aj jeho učitel'skej činnosti na danej škole a rozhovor prebehol bez akýchkol'vek komplikácií. Na otázky odpovedal priamo a snažil sa nám poskytnút’ čo najväčšie množstvo relevantných informácií. Zároveň, nám odporučil študentku na danej škole, Dominiku, ktorá 
je štvrtou respondentkou našej výskumnej činnosti a takisto nám sprostredkoval rozhovor s manželkou Jankou, ktorá je našou poslednou respondentkou

Posledná respondentka Janka, je manželkou respondenta Petra. Rozhovor sa realizoval $\mathrm{v}$ cukrárni, do ktorej pravidelne chodieva s rodinou a pri rozhovore bol prítomný aj jej manžel, neskôr aj dcéra. Rozhovor bol vel'mi príjemný, podnetný a plný rodinných zážitkov príbehov a skúseností. Počas svojho života ich postrehlo množstvo náročných situácií, no napriek tomu sa s nimi spoločne vysporiadali a sú dôkazom, že aj hendikepovaní l'udia sú schopní plnohodnotného partnerského vzt’ahu.

Jednotlivé odpovede našich respondentov boli zaznamenávané na diktafón a následne prepísané.

Skúmali sme postoj spoločnosti k zakladaniu rodín postihnutých. Na základe štúdia literatúry predpokladáme, že spoločnost' posudzuje telesne postihnutých jednotlivcov ako jednotlivcov, ktorí by si nemali zakladat' rodiny alebo by si mali udržiavat' len priatel'ské vzt'ahy, ktoré by nemali prerást' do partnerských či intímnych vzt'ahov. Respondent Janko je zo strany spoločnosti a svojich priatel'ov podporovaný. V rozhovoroch s manželským párom Pet'om a Jankou sme sa dozvedeli, že spoločnost' na ich rodinu reagovala negatívne. Ako príklad uviedli situácie, ktorým čelili počas pobytu v nemocnici počas tehotenstva alebo aj reakcie $\mathrm{z}$ rozhovoru $\mathrm{v}$ televíznych novinách či reakcie neznámych l'udí na verejnosti. $\mathrm{Z}$ daného rozhovoru vyplýva, že v spoločnosti sa stále vyskytujú názory, že telesne postihnutí jednotlivec by nemal vyhl'adávat' partnerské vzt'ahy a zakladat' rodinu, pretože je to nezodpovedné. Domnievame sa, že spoločnost' vníma jednotlivcov s telesným postihnutím ako l'udí, ktorí nie sú schopní úplného osamostatnenia sa a nezvládli by výchovu diet'at’a. Dominika v rozhovore poznamenala, že nemá žiadne skúsenosti so spoločnost'ou a jej postojom $\mathrm{k}$ partnerstvám zdravotne postihnutých jednotlivcov. Lucia nespomína žiadne predsudky, ohl'adom partnerského života postihnutých, pretože nemá žiadne skúsenosti. Druhá výskumná otázka overuje, či sa v spoločnosti stále vyskytuje množstvo mýtov o sexualite telesne postihnutých, ako napríklad, že u takýchto jednotlivcov absentuje možnost' zakladania rodiny alebo že takýto jednotlivci nie sú schopní nadviazat’ intímny vzt’ah. Otázka je zameraná na spoločnost' a mýty, ktoré sa v nej vyskytujú v oblasti sexuality telesne postihnutých. Domnievame sa, že spoločnost' nie je oboznámená s možnost’ami telesne postihnutých a vplyvom postihnutia na sexualitu jednotlivca s telesným postihnutím.

$\mathrm{V}$ rozhovore s Jankom neboli však spomínané žiadne príklady mýtov o sexualite telesne postihnutých, pretože sa so žiadnymi nestretol. Rozhovory s Pet'om a Jankou však obsahujú viac príkladov týkajúcich sa mýtov sexuality telesne postihnutých a to opät' u zdravotníkov a aj v bežnej spoločnosti. Jednou zo skúseností bola aj skúsenost' s medičkou, ktorá sa s prekvapením opýtala či je možné, aby telesne postihnutá žena mohla mat' diet’a. Z toho usudzujeme, že jeden z mýtov je, že jednotlivci s TP sú neplodní alebo nie sú schopní splodenia diet'at'a. S podobnými reakciami sa stretávali aj na verejnosti.

Opät' Dominika, v štvrtom rozhovore nemala žiadne skúsenosti s mýtmi o sexualite telesne postihnutých a myslíme, že daná situácia je spôsobená nedostatočným kontaktom $\mathrm{s}$ okolím.

Z rozhovorov d'alej vyplýva, že medzi najčastejšie mýty a predsudky, môžeme zaradit' predsudky spojené s možnost'ou nadviazania intímneho vzt’ahu, splodením diet'at'a a následne s vychovávaním diet'at'a v partnerskom vzt'ahu postihnutých.

Myšlienka, že telesne postihnutý jednotlivec nie je schopný nadviazania intímneho vzt'ahu, poprípade ak aj áno, tak nekvalitného pravdepodobne pramení z nedostatočnej informovanosti o živote postihnutých či z mylnej predstavy, že jednotlivec na vozíku je 
“ochrnutý od pása nadol” a tým pádom má úplne nefunkčné orgány, svaly a aj dolné končatiny. Možno čast' predsudkov u nás prevláda od dávnych čias, kedy sa jednotlivec $\mathrm{s}$ postihnutím považoval za neproduktívneho pre našu spoločnost' a nedostatočnou osvetou sa predsudky nevyvrátili, možno práve naopak, ešte viac sa rozšírili.

\section{References}

Baumeister, R. F. (1999). Self-concept, self-esteem, and identity. In V. J. Derlega, B. A. Winstead, \& W. H. Jones (Eds.), Nelson-Hall series in psychology. Personality: Contemporary theory and research (p. 339-375). Nelson-Hall Publishers. [in English].

Drábek, T. (2013). Partnerský a sexuální život osob se zdravotním postižením: publikace pro odborné sociální poradenství. Praha: Svaz tělesně postižených v České republice. [in Czech].

Erikson, H. (1968). Identity: Youth and crisis. New York: Norton. [in English].

Jaruš a Marková, D. (2007). Niektoré súčasné prístupy $k$ výskumu sexuality. [Electronic resource]. Retrieved from http://sex.systemic.cz/archive/cze/textbook2007/Markova.pdf. [in Slovak].

Katz, P. P., Gregorich, S., Eisner, M., Julian, L., Chen, H., Yelin, E., Blanc, P. D. (2010). Disability in Valued Life Activities Among Individuals With COPD and Other Respiratory Conditions. Journal of Cardiopulmonary Rehabilitation and Prevention, 30 (2), 126-136. DOI: 10.1097/HCR.0b013e3181be7e59. [in English].

Klimek, L., Klohna, B. (Eds.). (2001). Láska, partnerstvo, erotika a sexuálny život telesne postihnutých občanov. Prešov: ZOM. [in Slovak].

Kniha, M., Kaňák, J., Drábek, T., Krčmářová, B. (2014). Děti a jejich sexualita - rádce pro rodiče a pedagogy. Brně: Cpress. [in Czech].

Kracík, J. (1987). Kapitoly ze somatopedie - Výchova $k$ manželství a rodičovství. Praha: Státní pedagogické nakladatelství. [in Czech].

Mandzáková S., Horñák, L. (2009). Sexuálna výchova a príprava na poradenstvo osôb $s$ mentálnym postihnutím. Prešov: Prešovská univerzita v Prešove. [in Slovak].

Marcia, J. E. (1980). Identity in Adolescence. Handbook of Adolescent Psychology. New York: Wiley. [in English].

Mead, G. (1934). Mind, Self, and Society from the Standpoint of a Social Behaviorist. Chicago: University of Chicago Press. [in English].

Novosad, L. (2011). Tělesné postižení jako fenomén i životni realita. Praha: Portál. [in Czech].

Oyserman, D., Elmore, K., \& Smith, G. (2012). Self, self-concept, and identity. J. Tangney and M. Leary (Eds.). The Handbook of Self and Identity, pp. 69-104. New York, NY: Guilford Press. [in English].

Šillerová, M. (2004). Sigmund Freud a psychoanalýza jako nový prostor pro člověka 20. Století. [Diplomová práce]. Plzeň: Západočeská univerzita v Plzni. [in Czech].

Thorová, K., Hynek, J. (2012). Vztahy, intimita a sexualita lidí s mentálním handicapem nebo s autismem. Praha: Asociace pomáhající lidem s autismem. [in Czech].

WHO. (2002). Kvalita života, Zdravá sexualita. [in Czech].

Zvěrina, J. (2003). Sexuologie (nejen) pro lékaře. Brno: Akademické nakladatelství. [in Czech]. 